J. Clin. Chem. Clin. Biochem.

Vol. 20, 1982, pp. 15-24

\title{
The Sequence of Changes in the Biosynthesis of Sulfated Glycosaminoglycans in Acute, Experimental Liver Disease
}

\author{
By A. M. Gressner, Sylvia Heinrigs and $P$. Grouls \\ Department of Clinical Chemistry and Pathobiochemistry of the Medical Faculty, Technical University \\ (RWTH) Aachen, Aachen, FRG
}

(Received April 10/June 26, 1981)

Summary: The incorporation of $\left[{ }^{35} \mathrm{~S}\right]$ sulfate into total and specific glycosaminoglycans of the liver of rats injured acutely by a single intraperitoneal dose of either $D$-galactosamine ( 700 and $350 \mathrm{mg} / \mathrm{kg}$ body weight, respectively) or thioacetamide ( $100 \mathrm{mg} / \mathrm{kg}$ body weight) was studied in vivo and in liver slices. Regardless of the chemical nature of the hepatotoxic agent and its mechanism of action the incorporation of isotope in vivo is changed biphasically: a rapidly occurring and strong inhibition is followed by pronounced elevation in later stages of injury. In contrast to the dose-dependent inhibition of heparan sulfate formation the production of chondroitin sulfate and dermatan sulfate is only slightly and for a rather short period of time diminished. The synthesis of the latter glycosaminoglycans is stimulated 3 to 4 fold 8 to $24 \mathrm{~h}$ after onset of liver damage, that of heparan sulfate about 2 fold. Impaired synthesis of heparan sulfate occurs before the elevation of the activities of aspartate aminotransferase, alanine aminotransferase, and leucine arylamidase in serum. The specific radioactivity of 3 '-phosphoadenosine- 5 '-phosphosulfate remains nearly constant in galactosamine-damaged livers. Similar time-dependent changes of $\left[{ }^{35} \mathrm{~S}\right]$ sulfate incorporation into heparan sulfate, chondroitin sulfate and dermatan sulfate were measured in slices from livers injured in vivo for various times with $D$-galactosamine or thioacetamide. Neither serum from normal nor galactosamine-treated rats influences the total amount and the pattern of glycosaminoglycans synthesized in normal or injured liver slices. Hepatic glycosaminoglycan formation of 3.5 and 33 months old rats responds quantitatively and qualitatively in a similar way to $D$-galactosamine; $50 \%$ inhibition is reached with about $80 \mathrm{mg} / \mathrm{kg}$ of the hepatotoxin. The inhibition of heparan sulfate synthesis in early injured livers could not be reversed by addition of $p$-nitrophenyl- $\beta-D$-xylopyranoside to the medium (final concentration $1 \mathrm{mmol} / \mathrm{l}$ ), but in rats treated with diethyldithiocarbamate or the flavonoid (+)-cianidanol-3, prior to injection of $D$-galactosamine, a partial restoration of the diminished synthèsis of total glycosaminoglycans and of heparan sulfate is achieved.

\section{Die Sequenz der Ändenungen der Biosynthese sulfatierter Glykosaminoglykane bei akuten, experimentellen Lebererkrankungen}

Zusammenfasssung: Der Einbau von $\left[{ }^{35} S\right]$ Sulfat in die gesamten und spezifischen Glykosaminoglykane der Leber von Ratten, die akut geschädigt wurden durch eine intraperitoneale Einzelinjektion von entweder $D$-Galaktosamin $(7.00 \mathrm{mg} / \mathrm{kg}$ oder $350 \mathrm{mg} / \mathrm{kg} \mathrm{Körpergewicht)} \mathrm{oder} \mathrm{Thioacetamid}(100 \mathrm{mg} / \mathrm{kg})$, wurde in vivo und in Leberschnitten untersucht. Ungeachtet der chemischen Natur der hepatotoxischen Substanz und ihres Wirkungsmechanismus kommt es zu einer biphasischen Änderung des Isotopeinbaues: eine unmittelbar auftretende und starke Hemmung wird gefolğt von einer ạusgeprägten Erhöhung in späteren Stadien der Schädigung. Im Gegensatz zu der dosisabhängigen

. Hemmung der Heparansulfatbildung ist die Produktion von Chondroitinsulfat und Dermatansulfat nur geringfügig und während eines kürzeren Zeitraums vermindert.

Die Synthese der letztgenannten Glykosaminoglykane ist 3- bis 4-fach stimuliert 8 bis $24 \mathrm{~h}$ nach Beginn der Schädigung, die von Heparansulfat ungefähr 2-fach. Die beeintrạ̈chtigte Heparansulfatsynthese geht der Erhöhung der Aktivitäten von Älạninaminotransferase, Aspartataminotransferase und Leucinarylamidase im Serum zeitlich voraus. Die spezifische Radioaktivität von 3'-Phosphoadenosin-5'-phosphosulfat bleibt nạhezu konstant in Galaktosamingeschädigten Lebern. Ähnliche zeitabhängige Änderungen der $\left[{ }^{35} \mathrm{~S}\right]$ Sulfat Inkorporation in Heparansulfat, Chondroitinsulfat und Dermatansulfat wurden in Schnitten von Lebern gemessen, die für verschieden lange Zeiten in vivo mit $D$-Galaktosamin bzw. Thioacetamid vorgeschädigt wurden. Weder Serum von normalen noch Galaktosamin-behandelten 
Ratten beeinflußt die Menge und das Muster der in vitro von normalen und geschädigten Leberschnitten synthetisierten Glykosaminoglykane. Die Glykosaminoglykanbildung in den Lebern von 2,5 und 33 Monate alten Ratten wird in quantitativ und qualitativ gleicher Weise von $D$-Galaktosamin beeinflußt; $50 \%$ Hemmung wird erreicht bei einer Dosis der hepatotoxischen Substanz von ungefähr $80 \mathrm{mg} / \mathrm{kg}$ Körpergewicht. Die Hemmung der Heparansulfatsynthese in frühgeschädigten Lebern konnte nicht revertiert werden durch Zugabe von $p$-Nitrophenyl- $\beta$ - $D$-xylopyranosid zum Medium (Endkonzentration $1 \mathrm{mmol} / \mathrm{l}$ ) aber in Ratten, die vor der Galaktosamininjektion mit Diethyldithiocarbamat oder dem Flavonoid $(+)$ Cianidanol-3 behandelt wurden, ließ sich eine partielle Wiederherstellung der verminderten Synthese der gesamten Glykosaminoglykane und des Heparansulfates erreichen.

\section{Introduction}

The understanding of the metabolism of proteoglycans in liver is of great importance both from a physiological and pathobiochemical point of view. Normally the concentration of glycosaminoglycans, i.e. the polysaccharide side chains of proteoglycans, in liver is low (1-4), but they are metabolized at a rather high rate $(5,6)$. Heparan sulfate, the preponderant type of glycosaminoglycan in liver $(7,8)$ occurs predominantly in the microenvironment of the cell, i.e. the external surface of the hepatocyte $(6,9-12)$ and may there control the exchange of metabolites, ions, fluids, and water, exert some effects on hepatocellular proliferation and may regulate the accessibility of cell surface receptors (13-15). The physiological significance of the galactosamine containing sulfated glycosaminoglycans (chondroitin sulfate, dermatan sulfate) in liver is not known.

The concentration of heparan sulfate and also of chondroitin sulfate and dermatan sulfate in the distal portion of the intercellular space increases dramatically in longterm damaged livers, leading to the fibrotic transition of the tissue (for recent reviews see (16-18)). As discussed previously $(17,18)$ neither the cellular nor molecular pathobiochemical mechanism responsible for the accumulation of liver proteoglycans (and also of collagens) are well understood. The present work was undertaken to elucidate some principle features of glycosaminoglycan metabolism in acutely damaged livers which might be meaningful both for the pathobiochemistry of hepatocellular damage and for the pathogenesis of liver fibrosis, which develops if the hepatotoxic agent is applied continuously at a certain dose. Therefore the studies were performed in the early phases of two independent, well defined experimental models of liver disease, i.e. $D$ galactosamine hepatitis (19-21) and thioacetamideinduced liver injury $(22,23)$, which both result ultimately in liver fibrosis and cirrhosis (24-27).

\section{Materials and Methods}

The commercial sources and specifications of the following materials and reagents have been described previously $(4,28)$ : $D$-galactosamine hydrochloride, thioacetamide, phosphatebuffered saline, Dulbeccos modification of Eagles medium, carrier-free sodium [ ${ }^{35}$ S] sulfate, 3'-phosphoadenosine-5'phosphosulfate (tetrasodium salt, $\left.3^{\prime}-\gamma^{35} \mathrm{~S}\right]$ ), unlabeled glycosaminoglycans, chondroitin AC lyase (EC 4.2.2.5), chondroitin $\mathrm{ABC}$ lyase (EC 4.2.2.4), papain (EC 3.4.22.2), harmol $\cdot \mathrm{HCl}$, and thin-layer chromatography plates (CEL 300-25). Puromycindihydrochloride was purchased from Boehringer, Mannheim, FRG; dimethylsulfoxide (änalytical grade) was from E. Merck AG., Darmstadt, FRG; diethyldithiocarbamic acid (sodium salt, lot. $79 \mathrm{C}-0125$ ) and $p$-nitrophenyl $-\beta-D$-xylopyranoside (lot. $88 \mathrm{C}$ 0487) were from Sigma Chemical Comp., St. Louis, USA; $L-\left[4,5-{ }^{3} \mathrm{H}\right]$ leucine was from New England Nuclear, Boston, USA, and pentobarbital (Nembutal (pharm.)) from Serva, Heidelberg, FRG. (+)Cianidanol-3 (lot. N 2647, $3^{\prime}, 4^{\prime}, 5, \overline{7}$-tetrahy droxyflavanol) was kîndly provided by Zyma GmbH, Munich, FRG.

\section{Treatment of rats}

Male Sprague-Dawley rats (Lippischèe Vërsuchstieranstalt, Extertal, FRG) weighing 200-300 g had free access to a standard rat diet and water throughout the experimental period. Age-related studies were performed with 3.5 (bödy weight about $350 \mathrm{~g}$ ) and 33 months old (body weight about $600 \mathrm{~g}$ ) male Han: Wistar rats (Zentralinstitut für Versuchstiere, Hannover, FRG). Between 8:00 and 11:00 a.m. they were injected intraperitoneally either with $D$-galactosamine or thioacetamide both freshly dissolved in $0.154 \mathrm{~mol} / \mathrm{l}$ of $\mathrm{NaCl}$ (saline). The precise doses are given in the legends of the appropriate figures and tables. Control rats received: a similar volume of $\mathrm{NaCl}$ alone.

If the synthesis of liver glycosaminoglycans was studied in vivo the rats received, at certain times after application of the toxic agent and $30 \mathrm{~min}$ prior decapitation, $3.7 \mathrm{MBq}$ of $\left[{ }^{35} \mathrm{~S}\right]$ sulfate intraperitoneally. The liver was quickly excised, minced, washed in ice-cold phosphate-buffered saline and processed for the isolation of labeled gly cosamininoglycans as described below.

If the liver was used for preparation of slices the animals were anaesthetized by intraperitoneal injection of pentobarbital $(54 \mathrm{mg} /$ $\mathrm{kg}$ body weight). The livers were perfused in situ for $3 \mathrm{~min}$ with ice-cold phosphate-buffered saline at a flow rate of $30 \mathrm{ml} / \mathrm{min}$.

\section{Preparation and incubation of liver slices}

In principle the procedure described in detail previously was applied (5). In brief, slices of $0.5 \mathrm{~mm}$ thickness (about $100 \mathrm{mg}$ wet weight) were prepared manually and incubated for $3 \mathrm{~h}$ at $37^{\circ} \mathrm{C}$ and 90 oscillations/min in $3 \mathrm{ml}$ of Dulbeccos modification of Eagles medium ( $\mathrm{pH} 7.4$ ) under $\mathrm{O}_{2}-\mathrm{CO}_{2}$ mixture, volume fraction $0.95 / 0.05 .0 .93 \mathrm{MBq}(50 \mu \mathrm{l})$ of $\left[{ }^{35}\right.$ S] sulfate were added at the beginning of the incubation. At the end, the slices were washed briefly in ice-cold buffered saline and transfered immediately into about $10 \mathrm{ml}$ of cold acetone.

\section{Measurement of the incorporation of $\left[^{35} \mathrm{~S}\right]$ sulfate into total} and specific glycosaminoglycans

The livers labeled in vivo and the slices labeled in vitro with $\left.{ }^{35} \mathrm{~S}\right]$ sulfate were repeatedly washed (defatted) in cold acetone, chloroform-methanol $(200 \mathrm{ml})$ and ethanol-ether $(300 \mathrm{ml}) \cdot$ after which the material was dried for $24 \mathrm{~h}$ at $60^{\circ} \mathrm{C}$. The delipidized slices were homogenized in $5 \mathrm{ml}$ of buffered papain (29) from which an aliquot was taken for the determination of protein with 


\section{Walter de.Gruyter Berlin-New York}

\section{E. Buddecke \\ Biochemische Grundlagen der Zahnmedizin}

$17 \mathrm{~cm} \times 24 \mathrm{~cm}$. XV, 193 Seiten. 90 Abbildungen. 19 Tabellen. 1981. Flexibler Einband. DM 36,- ISBN 3110087383

Das Kurzlehrbuch für Zahnärzte und Studierende behandelt die Biochemie der Zähne, des Zahnhalteapparates und der Mundhöhle. Es werden Chemie und Stoffwechsel der organischen Matrix der Zahnhartsubstanz, Biomineralisation, Fluoridstoffwechsel und die spezielle Biochemie des Speichels und der Mikroorganismen der Mundhöhle beschrieben. Sie bilden die Grundlage für die Pathobiochemie der beiden häufigsten Erkrankungen der Odontologie - der Karies und der Parodontopathie. Die Darstellung umfaßt neben pathogenetischen auch präventive Aspekte der Karies und Parodontopathie sowie eine Übersicht über die chemische Zusammensetzung und Wirkungsweise von Zahnpflegemitteln.

Der behandelte Inhalt des Buches berücksichtigt auch die Prüfungsordnung fürr Zahnärzté.

Aus dem Inhalt (Hauptkapitel):

Zahnmedizin uñd Biochemie $\cdot$ Chemie der anorganischen und orgañischen Bestandteile der Zahnhartgewebe :

Stoffwechsel der organischen Matrix von Zähnen und Knochen · Biomineralisation Regulation des Hartgewebëstoffwechsels - Topochemie der Zahn hartgewebe - Biochemie des Fluors Speicheldrüsen und Speichel' - Mikroorganismen der Mụndhöhle . Pathobiochemie der Karies . Kariesabwehr und Kariesprophylaxe . Gingiva, Parodont und Parodontopathie . Chemische Zusammensetżung von Zahnpflegemitteln · Mundhöhle und Allgemeinstoffwechsel.
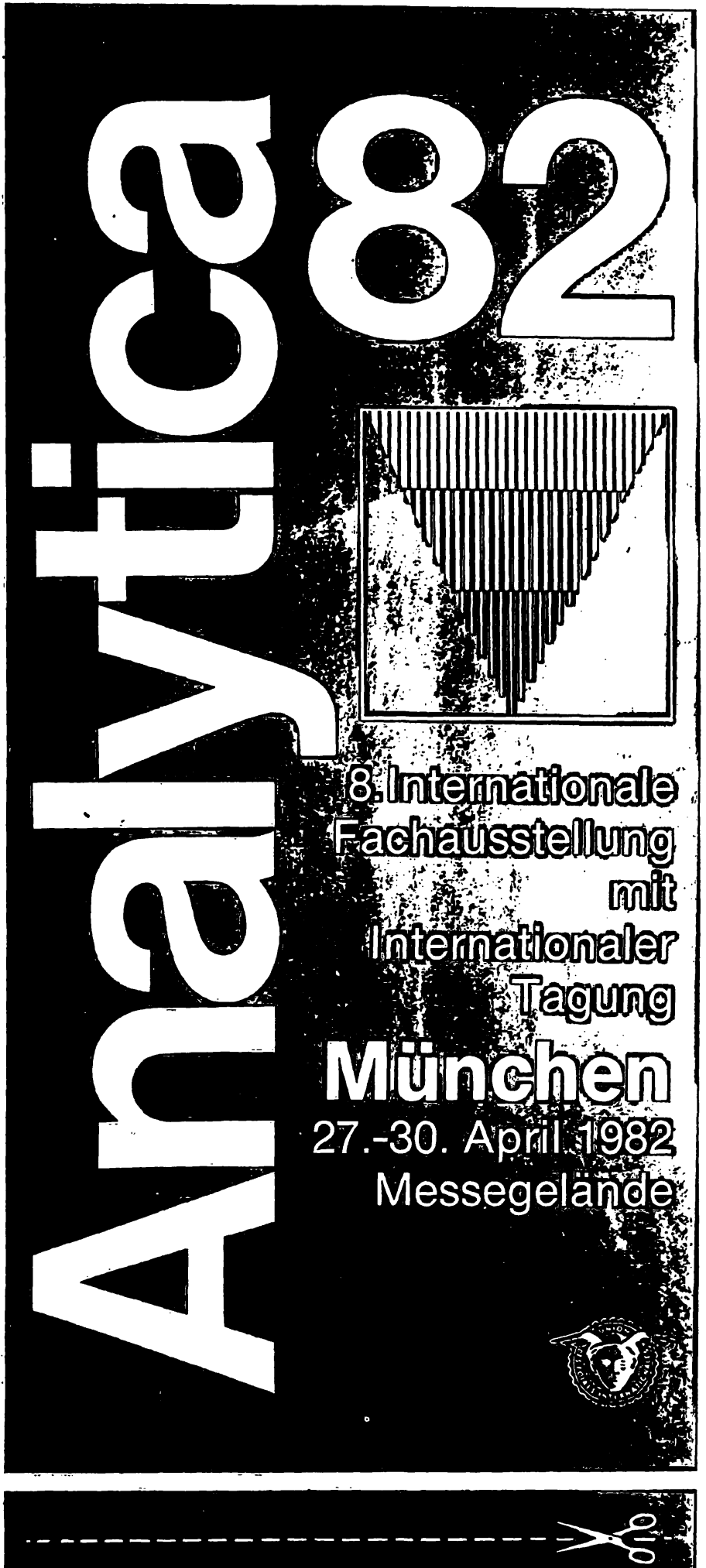

Coupon - Analytica 82

Bitte senden Sie mir nähere Informationen

Name

Anschrift

Münchener Messe- und Ausstellungsgesellschaft $\mathrm{mbH}$ Messegelände. Postfach 1210 09, 8000 München 12 Tel.: (089) 51 07-1, Telex 5212086 ameg d. 


\section{Waiter de Gruyter Berlin.New York}

\section{Terrance G. Cooper Biochemische Arbeitsmethoden}

Übersetzt und bearbeitet von Reinhard Neumeier und $\mathrm{H}$. Rainer Maurer

$17 \mathrm{~cm} \times 24 \mathrm{~cm}$. XVI, 416 Seiten. 247 Abbildungen. 56 Tabellen. 1980. Fester Einband. DM 68,- ISBN 3110078066

\section{J. Paul}

\section{J. Buddrus}

\section{N. L. Allinger et al.}

\section{S. B. Pal}

(Editor)

\section{Zell- und Gewebekulturen}

Übersetzt von Sigrid Maurer und Rainer Maurer $15,5 \mathrm{~cm} \times 23 \mathrm{~cm}$. XVIII, 486 Seiten. 28 Seiten Tafeln.

57 Abbildungen. 1980. Fester Einband. DM 70,ISBN 3110070197

\section{Grundlagen der Organischen Chemie}

$17 \mathrm{~cm} \times 24 \mathrm{~cm}$. XXV, 754 Seiten. 1980. Fester Ëinband. DM 59,ISBN 3110040301

\section{Organische Chemie}

von N. L. Allinger, M. P. Cava, D. C. de Jongh, C. R. Johnson, N. A. Lebel, C. L. Stevens.

Übersetzt und bearbeitet von $\mathrm{H}$. Gnichtel, F. Klages,

G. Koßmehl, H. Kurreck, G. Manecke.

Wissenschaftliche Redaktion: $\mathrm{G}$. KoBmehl.

$18 \mathrm{~cm} \times 26 \mathrm{~cm} . X X X, 1570$ Seiten. Zahlreiche Abbildungen und Tabellen. 1980. Fester Einband. DM 98,ISBN $311004594 \mathrm{X}$

\section{Begleitbuch zu}

Allinger $u$. a.

Organische Chemie

Antworten zu den Übungsaufgaben

$18 \mathrm{~cm} \times 26 \mathrm{~cm}$. VI, 118 Seiten. Flexibler Eiñband. DM 16,80 ISBN 3110082489

\section{Enzyme Labelled Immunoassay of Hormones and Drugs}

Proceedings of the International Symposium on Enzyme Labelled Immunoassay of Hormones and Drugs, UIm, West Germany, July 10 and 11, 1978.

$1978.17 \mathrm{~cm} \times 24 \mathrm{~cm}$. XXV, 475 pages. With 35 illustrations. Hardcover. DM 130,- ISBN 3110075393

Preisänderungen vorbehalten 
the Lowry procedure, using bovine serum albumin as a standard (30). In vivo labeled, defatted and dried tissue was weighed prior to suspension in buffered papain. The tissue was exhaustively proteolysed with papain (5). From the proteolysed, trichloroacetic acid-soluble, and dialysed material $\left.\right|^{35} \mathrm{~S}$ ]-labeled glycosaminoglycans together with added unlabeled glycosaminoglycans as carrier were precipitated with cetylpyridinium chloride as described previously (5). The radioactivity of the isolated glycosaminoglycans was measured and refered to defatted liver dry weight (in vivo experiments) and protein (in vitro).

For differentiation of specific types, the unfractionated glycosaminoglycans were subjected to enzymatic degradation with chondroitin $\mathrm{AC}$ and $\mathrm{ABC}$ lyases to yield the incorporation of $1^{35}$ S $]$ sulfate into chondroitin 4,6-sulfate and dermatan sulfate, respectively. They were also degraded with nitrous acid to measure the heparan $\left[^{35} \mathrm{~S}\right]$ sulfate (5). Synthesis of specific glycosaminoglycans is expressed either in absolute terms (Bq/g protein), or relatively as a fraction of total glycosaminoglycan synthesis.

Determination of the concentration and specific radioactivity of 3'-phosphoadenosine-5'-phosphosulfate (PAPS) in liver Concentration and specific radioactivity of PAPS in normal, galactosamine- and thioacetamide-damaged livers were assayed by the fluorimetric procedure of Ping Wong \& Yeo (31) modified slightly as previously reported (28). For this purpose an aliquot of the $\left[{ }^{35}\right.$ S $]$-labeled liver was pulverized in liquid nitrogen from which PAP $\left.\right|^{35} \mathrm{~S}$ ] was extracted with chloroform. In the presence of a dog liver $178,000 \mathrm{~g}$ supernatant the PAPS-bound $\left.\right|^{35}$ S] sulfate is transfered quantitatively to harmol. Labeled harmol sulfate was separated from harmol by thin-layer chromatography and quantitated as reported (28).

Measurement of the incorporation of $L-\left[{ }^{3} \mathrm{H}\right]$ leucine into protein of liver slices

Slices from normal and injured livers were incubated for $3 \mathrm{~h}$ at $37^{\circ} \mathrm{C}$ in Dulbeccos medium containing $0.19 \mathrm{MBq}$ of $L-\left[4,5-{ }^{3} \mathrm{H}\right]$ leucine. At the end of incubation the slices were quickly washed in ice-cold buffer, boiled for $3 \mathrm{~min}$, dried, and homogenized in $2 \mathrm{ml}$ of destilled water from which an aliquot was taken for the determination of protein (30). $100 \mu$ l portions of the homogenate were spotted on Whatman 3 MM filter paper disks and sequentially extracted according to the technique of Mans \& Novelli (32). The incorporation of $\left.i^{3} \mathrm{H}\right]$ leucine is refered to the protein content of the slice.

\section{Collection of blood and determination of serum enzyme activities}

Blood was aspirated from the $V$. cava inf. of the anaesthetized rat and nonhaemolytic serum prepared. The activities of alanine aminotransferase (EC 2.6.1.2) (33), aspartate aminotransferase (EC 2.6.1.1) (34) and leucine arylamidase (EC 3.4.11.) (35) were measured. The first two were determined in a DuPont Automatic Clinical Analyzer, the latter in the Eppendorf enzyme automate ACP 5040. The serum used for incubation studies was prepared freshly and stored in ice until use.

\section{Results}

\section{Synthesis of glycosaminoglycans in acutely injured rat liver in vivo}

In response to the administration of a single dose of $D$-galactosamine ( $350 \mathrm{mg} / \mathrm{kg}$ body weight) to rats the incorporation of $\left[{ }^{35} \mathrm{~S}\right]$ sulfate into total liver glycosaminoglycans is depressed rapidly and to a great extent (fig. 1a). $30 \mathrm{~min}$ after induction of liver injury the incor-

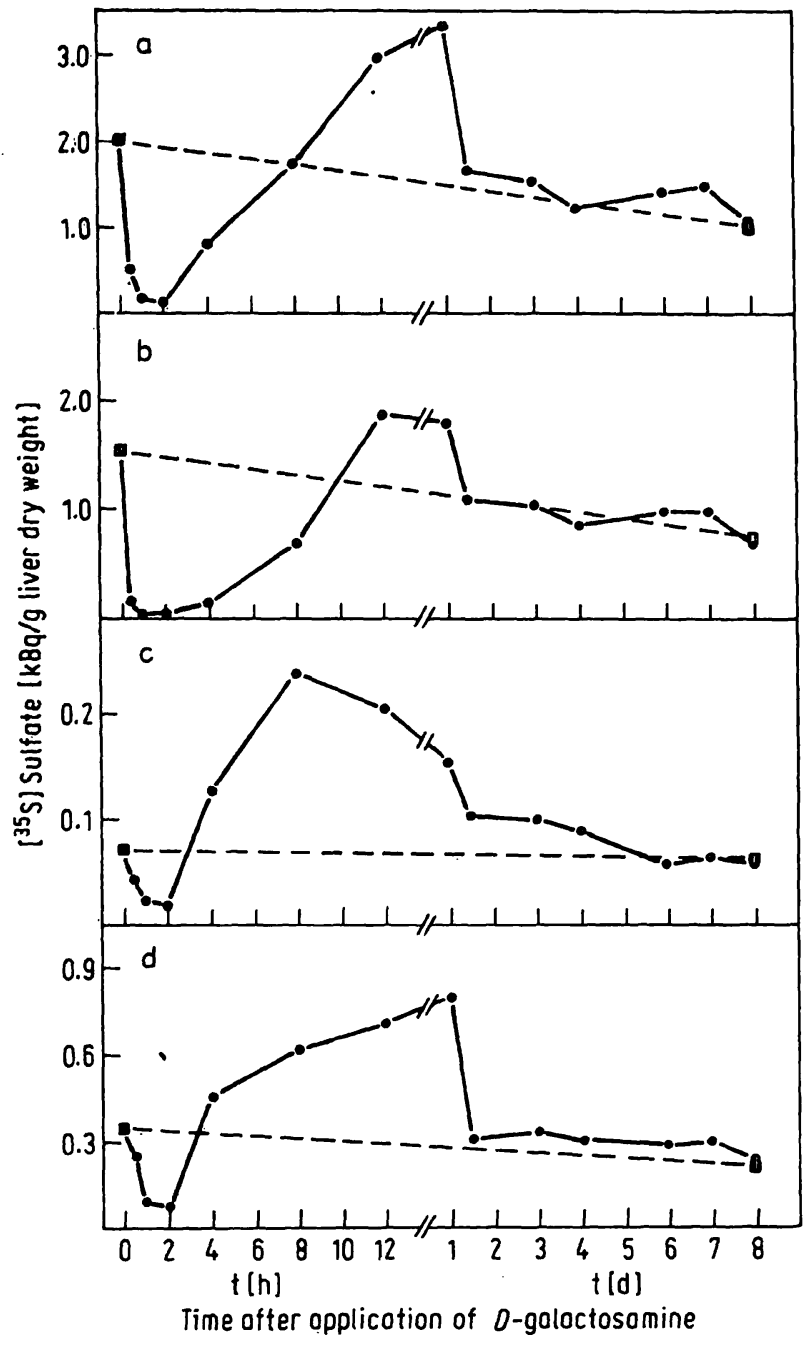

Fig. 1. Incorporation of $\left[^{35} \mathrm{~S}\right]$ sulfate into hepatic glycosaminoglycans of rats injured with $D$-galactosamine.

Rats received between 8.00 and $9.00 \mathrm{a} . \mathrm{m}$. a single dose of $350 . \mathrm{mg} / \mathrm{kg}$ body weight of $D$-galactosamine i. p. and at various times thereafter $3.7 \mathrm{MBq}$ of $\left.\right|^{35} \mathrm{~S}$ ] sulfate $30 \mathrm{~min}$ before sacrification. The livers were removed, defatted, dried, and subjected to proteolysis. Total glycosaminoglycans were isolated and determined by chemical and enzymatic procedures. At the beginning (day 0 ) and the end (day 8) of the study 3 control rats (injected with saline instead of galactosamine), respectively, were analysed in a similar way ( $-\cdots)$. Each time point represents the mean value of 3 separate experiments. the CV was within $20 \%$.

The incorporation of $\left.\right|^{35} \mathrm{~S}$ |sulfate into total glycosaminoglycans (a), heparan sulfate (b), chondroitin sulfate (c). and dermatan sulfate (d) is shown.

poration is reduced by about $75 \%$ reaching the lowest values after $2 \mathrm{~h}$. Later on the rate of incorporation increases gradually and climaxes between 24 and $48 \mathrm{~h}$. At this time the labeling of glycosaminoglycans is nearly twice that found in the respective control livers. 3 to 4 days after application of the drug $\left[{ }^{35} \mathrm{~S}\right]$ sulfate incorporation into glycosaminoglycans is similar to that in normal livers. 
Qualitatively similar biphasic changes were found for the production of heparan $\left[{ }^{35} \mathrm{~S}\right]$ sulfate (fig. $1 \mathrm{~b}$ ) but its inhibition takes longer and is more severe (nearly complete inhibition between 0.5 and $4 \mathrm{~h}$ ) and its stimulation is less than that of total glycosaminoglycans. This observation suggests that the production of the other types of sulfated glycosaminoglycans, i.e. of chondroitin sulfate and/or dermatan sulfate, is differently affected in injured livers. Figure $\mathrm{Ic}$ and $\mathrm{ld}$ substantiate that the incorporation of $\left[{ }^{35} \mathrm{~S}\right]$ sulfate into these types of glycosaminoglycans is inhibited only for a short period and to a small extent when compared to heparan sulfate. Instead, their synthesis is greatly, i.e. 3- to 4-fold exaggerated 8 to $24 \mathrm{~h}$ after induction of liver damage. At a time point $(4 \mathrm{~h})$ when heparan sulfate production is nearly completely depressed, the incorporation of $\left[{ }^{35} \mathrm{~S}\right]$ sulfate into chondroitin sulfate is 2 times that measured in control livers.

The duration of the inhibitory phase is dose-dependent; with $700 \mathrm{mg} / \mathrm{kg}$ of $D$-galactosamine the inhibition of heparan $\left[{ }^{35} \mathrm{~S}\right]$ sulfate synthesis is extended to 3 days, that of total glycosaminoglycan production to 1 day (not shown). This; again, indicates a strong stimulation of the formation of the remaining types of glycosaminoglycans (chondroitin sulfate, dermatan sulfate) between 1 and 3 days after onset of injury.

The specific radioactivity of liver 3 '-phosphoadenosine5 '-phosphosulfate (PAPS) does not change significantly in $D$-galactosamine-injured rat liver, although its concentration in the tissue was found to be reduced by $50 \%$ 2 days after initiation of liver damage (tab. 1). Thus, the changes in the rates of incorporation of $\left[{ }^{35} \mathrm{~S}\right]$ sulfate into glycosaminoglycans observed in injured liver seem to be a true reflection of the biosynthesis of these complex glycoconjugates.

Acute thioacetamide-induced liver damage $(100 \mathrm{mg} / \mathrm{kg}$ body weight), resulted in biphasic changes of total and specific hepatic glycosaminoglycan synthesis, qualitatively very similar to those described for galactosamine (results not shown). Thus, the changing pattern of glycosaminoglycan synthesis obviously is not related to the chemical nature and the mechanism of action of the hepatotoxic compound.

\section{Synthesis of glycosaminoglycans in slices from livers injured in vivo with $D$-galactosamine or thioacetamide}

The time-dependent changes of the synthesis pattern of sulfated glycosaminoglycans were studied in more detail in slices derived from in vivo preinjured livers, thus eliminating in part possible influences of extrahepatic factors. In accordance with the in vivo results (fig. 1) slices from galactosamine-damaged liver $(350 \mathrm{mg} / \mathrm{kg}$ body weight) show a strong impairment of their glycosaminoglycan synthesis between 0.5 and $6 \mathrm{~h}$ after onset
Tab. 1. Concentration and specific radioactivity of $3^{\prime}$-phosphoadenosine-5'-phosphosulfate in rat liver following administration of $D$-galactosaminc.

Rats were injected with $700 \mathrm{mg} / \mathrm{kg}$ body weight of $D$. galactosamine and received, at the times indicated, $30 \mathrm{~min}$ before sacrification, $3.7 \mathrm{MBq}$ of [ $^{35}$ S] sulfate. Portions of the liver were frozen in liquid nitrogen, weighed and applied to fluorimetric quantitation and determination of specific activity of $3^{\prime}$-phosphoadenosine $5^{\prime}$-phosphosulfate. The mean values $\pm S$. P. of 3 to 4 independent experiments are given.

\begin{tabular}{|c|c|c|c|}
\hline $\begin{array}{l}\text { Treatments } \\
\text { of rats }\end{array}$ & $\begin{array}{l}{\left[{ }^{35} \mathrm{~S}\right]-} \\
\text { sulfate } \\
\text { injec- } \\
\text { tion } \\
\text { after }\end{array}$ & $\begin{array}{l}\text { Concentration } \\
\text { of } 3^{\prime} \text {-phospho- } \\
\text { adenosine-5'- } \\
\text { phosphosulfate } \\
\text { (nmol/g liver } \\
\text { ivet weight) }\end{array}$ & $\begin{array}{l}\text { Specific radio- } \\
\text { activity of } \\
3^{\prime} \text {-phospho- } \\
\text { adenosine-5'- } \\
\text { phosphosulfate } \\
\text { (Bq/nmol) }\end{array}$ \\
\hline $\begin{array}{l}\text { No (control) } \\
D \text {-galactosamine } \\
D \text {-galactosamine } \\
D \text {-galactosamine }\end{array}$ & $\begin{array}{r}\overline{2} \mathrm{~h} \\
12 \mathrm{~h} \\
48 \mathrm{~h}\end{array}$ & $\begin{array}{l}21.1 \pm 2.6 \\
25.0 \pm 2.4 \\
13.4 \pm 1.4 \\
11.0 \pm 2.7\end{array}$ & $\begin{array}{l}24.9 \pm 4.3 \\
24.5 \pm 3.5 \\
24.1 \pm 5.1 \\
20.0 \pm 4.9\end{array}$ \\
\hline
\end{tabular}

of injury (fig. 2a). 2 days later the incorporation of $\left[{ }^{35} \mathrm{~S}\right]$ sulfate into total glycosaminoglycans is stimulated by more than $50 \%$. The formation of heparan $\left[{ }^{35} \mathrm{~S}\right]$ sulfate exhibits similar time-dependent changes (fig. $2 \mathrm{~b}$ ). lts depression, however, is more severe than that of total glycosaminoglycans which is due to an additional decline in the relative proportion of heparan $\left[{ }^{35} \mathrm{~S}\right]$. sulfate production. Normally this glycosaminoglycan represents a fraction of about 0.85 of total glycos: aminoglycan synthesis but in injured liver its portion is only about 0.5 (fig. 2b). The loss of heparan sulfate is "compensated" by a strong relative increase in the production of both chondroitin sulfate and dermatan sulfate (fig. 2c). The incorporation of $\left[{ }^{35} \mathrm{~S}\right]$ sulfate into these polysaccharides is only slightly and for a short period of time reduced, but a 3-fold (dermatan sulfate) and a nearly 5 -fold (chondroitin sulfate) stimulation were observed after 24 to $48 \mathrm{~h}$ (fig. 2c). Compared with the time-course of the incorporation of $\left[{ }^{3} \mathrm{H}\right]$ leucine into total protein during the first $6 \mathrm{~h}$ after galactosamineprovoked liver damage, the formation of chondroitin sulfate and dermatan sulfate, in contrast to that of heparan sulfate, seems to be rather independent of protein synthesis (fig. 2a, inset).

The time-course of $\left[{ }^{35} \mathrm{~S}\right]$ sulfate incorporation into total glycosaminoglycans in slices prepared from liver in the state of low (time of injury $4 \mathrm{~h}$ ) or high (time of injury $48 \mathrm{~h}$ ) glycosaminoglycan synthesis indicates that the incorporation in the latter is linear only up to $6 \mathrm{~h}$, whereas the former (and control liver slices) exhibits linearity at least up to $8 \mathrm{~h}$ of incubation (fig. 3a). It is important to note that the fraction of heparan $\left[{ }^{35} \mathrm{~S}\right]$ sulfate is not influenced by the time of incubation, and is only dependent on the duration of injury, i.e. in the early injured liver the portion of heparan sulfate is smallest $(0.55$ instead of 0.8 in control liver slices, fig. $3 b$ ). 


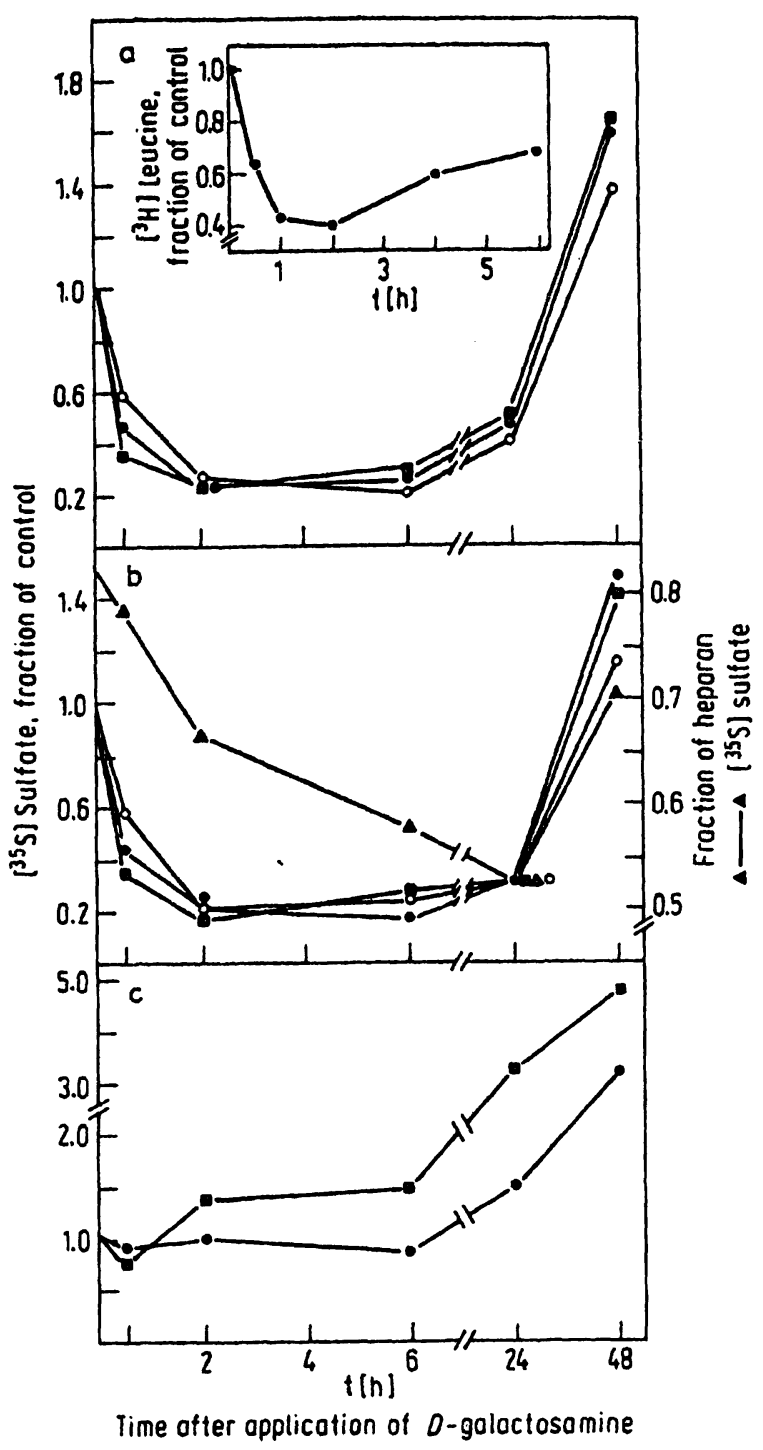

Fig. 2. The time-dependence of the effect of $D$-galactosamine on the incorporation of $\left.\right|^{35}$ S $\mid$ sulfate into glycosaminoglycans of liver slices relative to that of untreated (saline injected) rats.

Rats were injected with a single dose of $350 \mathrm{mg} / \mathrm{kg}$ body weight of $D$-galactosamine and at various times thereafter anaesthetized. The livers twere perfused with cold phosphate-buffered saline. and excised for the preparation of slices. The explants were inculated for $3 \mathrm{~h}$ at $37^{\circ} \mathrm{C}$ in medium containing $0.93 \mathrm{MBq}$ of $\left.\right|^{35} \mathrm{~S}$ / sulfate either in the absence $(a . b \circ-0)$ or presence of $0.2 \mathrm{ml}$ serum from normal $(a, b \bullet-\bullet)$ and galactosamine $(a, b=-\infty)$ treated rats. The incorporation of $\left[^{35} \mathrm{~S}\right]$ sulfate into glycosuminoglycans of liver slices from galactosamine-treated rats is expressed as the proportion of that of control livers incubated under identical conditions. Each time point is the mean value of 3 experiments, the $C V$ was within $15 \%$. The relative incorporation into total glycosaminoglycans (a), heparan sulfate (b), dermatan sulfate (c. $\bullet-\bullet)$ ) and chondroitin sulfate (c. - - i), is shown. In (b) heparan sulfate is expressed also as fraction of total labeled glycosaminoglycans (A-A). The inset in (a) represents the incorporation of $i^{3} \mathrm{H}$ )leucine into total protein of slices from livers treated for various times with $350 \mathrm{mg} / \mathrm{kg}$ body weight of $D$-galactosamine, expressed as fraction of that measured in the respective control liver slices.

Total and specific glycosaminoglycan synthesis in slices from acute thioacetamide-injured livers behaves similarly to that in galactosamine-damaged tissue (fig. 4). There is

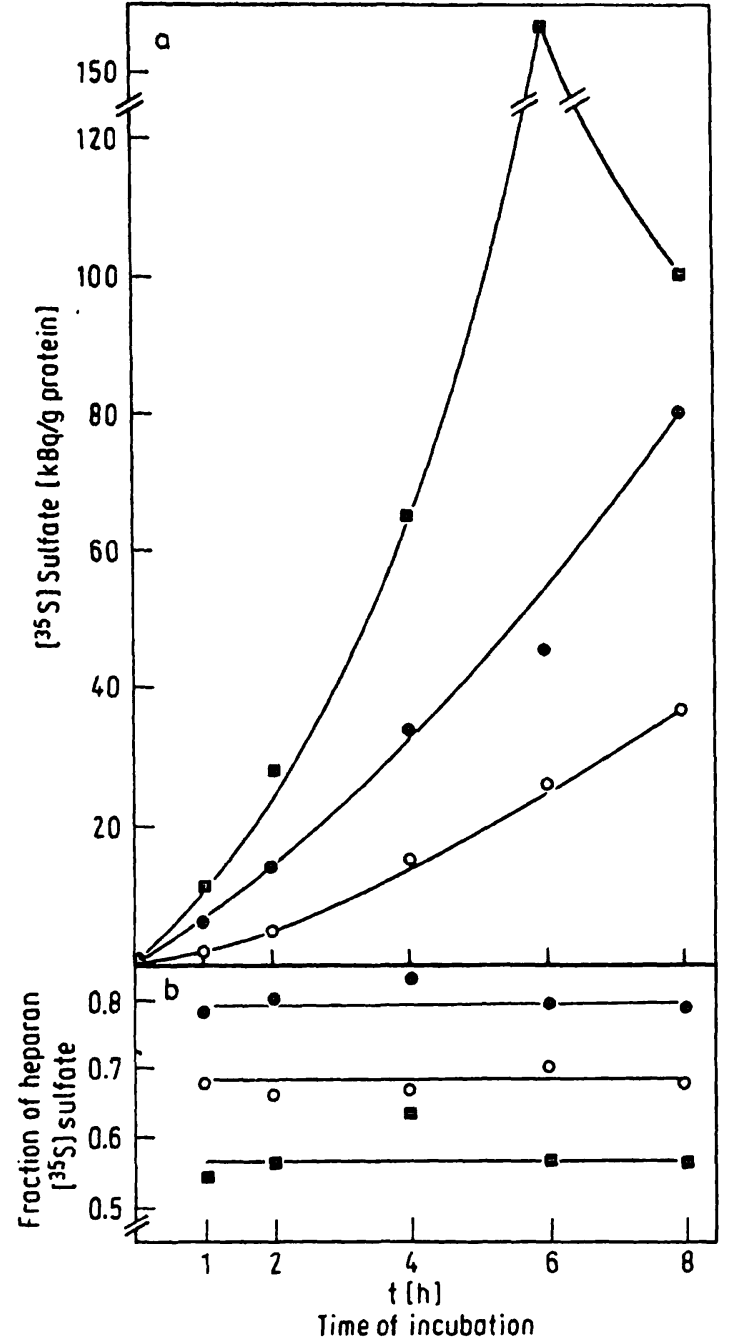

Fig. 3. The effect of galactosamine-induced liver injury on the time-course of the incorporation of $\left.\right|^{35} \mathrm{~S} /$ sulfate into glycosaminogly cans of liver slices.

Rats were treated with a single dosc of $350 \mathrm{mg} / \mathrm{kg}$ body weight of $D$-galactosamine; control rats received a similar

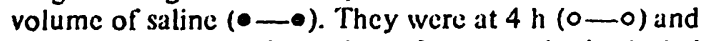
$48 \mathrm{~h}(-\infty)$ respectively thereafter anaesthetized; their livers were perfused with cold buffer and slices prepared and incubated at $37^{\circ} \mathrm{C}$ for various times in medium containing $\left.\right|^{35} \mathrm{~S} \mid$ sulfate. The incorporation of the label into total glycosaminoglycans (a) and the proportion of heparan $\left.\right|^{35}$ S|sulfate (b) during incubation is shown.

a lack of inhibition of dermatan $\left[{ }^{35} \mathrm{~S}\right]$ sulfate formation but a strong relative and absolute decrease of heparan $\left[{ }^{35} \mathrm{~S}\right]$ sulfate production $24 \mathrm{~h}$ after application of the drug. At 2 days the incorporation of $\left[{ }^{35} \mathrm{~S}\right]$ sulfate into dermatan sulfate is enhanced 4-fold which is accompanied by a significant but less pronounced stimulation on the synthesis of total glycosaminoglycans and of heparan sulfate (fig. 4b). It should be emphasized that the depression of liver heparan sulfate synthesis occurs before the activities in serum of alanine aminotransferase, aspartate aminotransferase, and leucine arylamidase increase (fig. 4b). The relationship between the synthesis of glycosaminoglycans and incorporation of $\left[{ }^{3} \mathrm{H}\right]$ leucine into protein (fig. 4c) is identical to that described for galactosamine hepatotoxicity. 


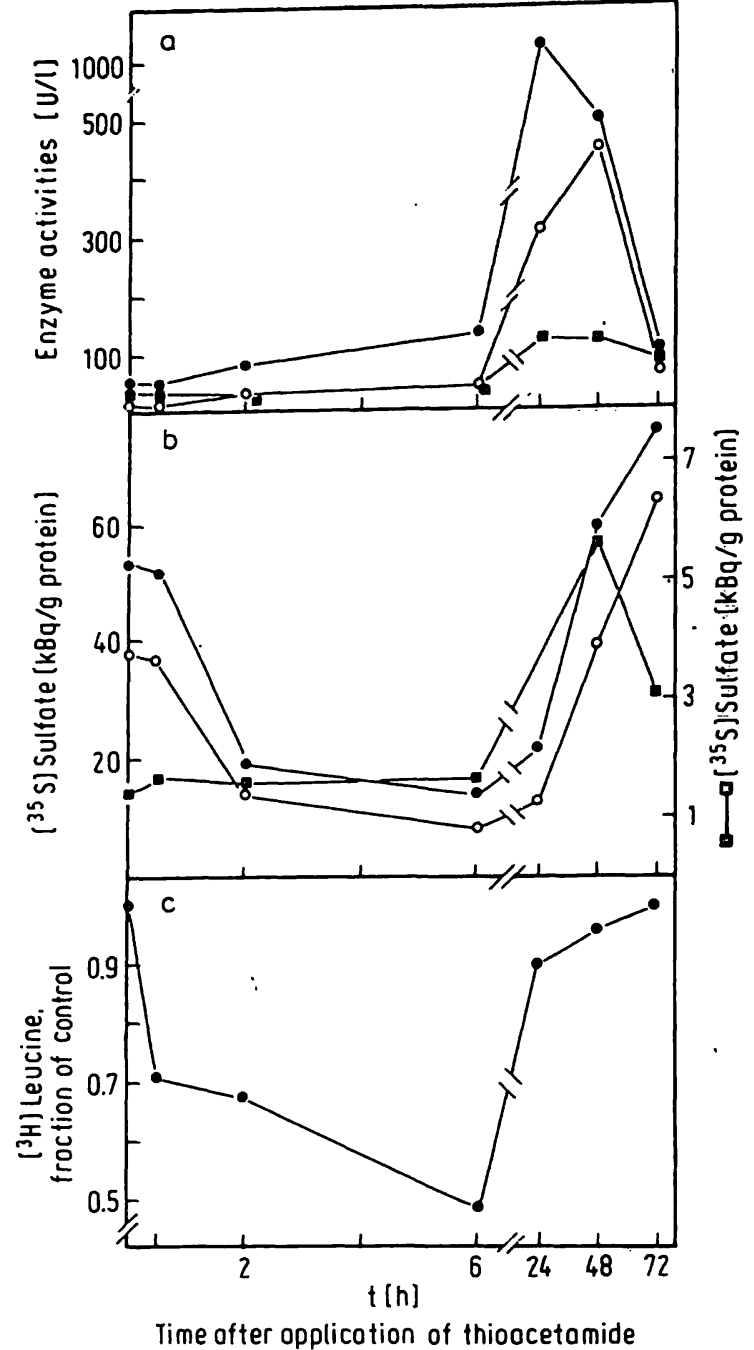

Effect of age of the rat on galactosamine-induced inhibition of liver glycosaminoglycan synthesis

The sensitivity of hepatic glycosaminoglycan formation to $D$-galactosamine was tested in relation to the age of the rat. No significant differences were found in the
Fig. 4. The time-dependence of the effect of thioacetamide on the synthesis of glycosaminoglycans and proteins in liver slices and on the enzyme activities in serum.

Rats were treated with a single dose of $100 \mathrm{mg} / \mathrm{kg}$ body weight of thioacetamide or a similar volume of saline (control rats) and at various times thereafter anaesthetized, their livers were perfused with cold buffer and slices prepared. Incubation of the explants was for $3 \mathrm{~h}$ in the presence of $0.93 \mathrm{MBq}$ of [ ${ }^{3.5} \mathrm{~S}$ ] sulfate. The incorporation of the isotope into total glycosaminogly cans $(b, \bullet-\bullet)$, heparan sulfate $(b, 0-0)$, and dermatan sulfate $(b$, - - ) was measured.

The incorporation of $\left.~_{3} \mathrm{H}\right]$ leucine into the proteins of thioacetamide-injured liver slices expressed as fraction of that measured in control rat liver explants is shown in (c). (a) represents the cataly tic concentrations of aspartate

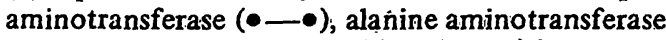
$(0-0)$, and leucine arylamidase (- -1$)$ in serum.

dose-dependent inhibition of the synthesis of total glycosaminoglycans and of heparan sulfate in liver slices of 33 months and 3.5 months old rats. $50 \%$ inhibition is reached at a dose of about $80 \mathrm{mg} / \mathrm{kg}$ of $D$-galactosamine. Moreover, the relative portion of heparan $\left[{ }^{35} \mathrm{~S}\right]$ sulfate declined similarly for both age groups, from about 0.75 to $0.45-0.55$. This implies a concomitant increase in the fraction of galactosamine-containing sulfated glycosaminoglycans. Young rats with elevated activities of alanine aminotransferase in their serum show a somewhat stronger inhibition of $\left[{ }^{35} \mathrm{~S}\right]$ sulfate incorporation into glycosaminoglycans than those having (still) normal serum enzyme activities.

\section{Effect of serum from normal and injured rats on the synthesis of glycosaminoglycans in slices from normal and injured liver}

To define possible humoral regulators of hepatic glycosaminoglycan syñthesis, slices from normal and diseased liver were incubated in the presence or absence of serum from normal and injured rats. Results summarized in table 2 indicate that the incorporation of $\left[{ }^{35}\right.$ S ] sulfate

Tab. 2. The effect of serum from galactosamine-treated and untreated (control) rats on the synthesis of total glycosaminoglycans and heparan sulfate in slices from untreated (control) and galactosamine-injured livers.

Rats received $350 \mathrm{mg} / \mathrm{kg}$ body' weight of $D$-galactosamine i.p. or a similar volume of $0.154 \mathrm{~mol} / \mathrm{l}$ of $\mathrm{NaCl}$ i.p. and were sacrified at various times thereafter. Blood was aspirated from the V. cava inf. of the anaesthetized (pentobarbital) animals and the liver perfused through the V. porta with ice-cold phosphate buffered saline. Slices from livers were prepared and incubated for $3 \mathrm{~h}$ in $2.8 \mathrm{ml}$ of Dulbeccos medium containing $0.93 \mathrm{MBq}$ of $\left.1^{35} \mathrm{~S}\right]$ sulfate in the absence or presence of $0.2 \mathrm{ml}$ of the respective serum. The incorporation of $\left[^{35} \mathrm{~S}\right]$ sulfate into glycosaminoglycans is refered to the protein content of the liver slice. The values are the mean of triplicate experiments, the CV was within 12\%. The synthesis of heparan sulfate as a fraction of total glycosaminoglycan production is given in parentheses.

Time (h) after application of galactosamine or $\mathrm{NaCl}$
Total glycosaminoglycan synthesis $(\mathrm{kBq} / \mathrm{g}$ protein) and fraction of heparan sulfate (in brackets)

\begin{tabular}{|c|c|c|c|c|c|}
\hline No serum & $\begin{array}{l}\text { Normal liver } \\
\text { Normal serum }\end{array}$ & $\begin{array}{l}\text { "Galactos- } \\
\text { amine" serum }\end{array}$ & No serum & $\begin{array}{l}\text { ctosaminc liver } \\
\text { Normal serum }\end{array}$ & $\begin{array}{l}\text {,Galactos- } \\
\text { amine" serum }\end{array}$ \\
\hline $\begin{array}{l}49.7(0.86) \\
54.9(0.79) \\
40.7(0.85) \\
31.2(0.86) \\
34.8(0.77)\end{array}$ & $\begin{array}{l}44.4(0.81) \\
47.9(0.80) \\
38.7(0.84) \\
33.5(0.74) \\
32.4(0.80)\end{array}$ & $\begin{array}{l}47.4(0.78) \\
58.6(0.75) \\
42.2(0.87) \\
32.6(0.82) \\
27.6(0.81)\end{array}$ & $\begin{array}{l}23.3(0.79) \\
13.4(0.67) \\
10.8(0.58) \\
15.1(0.52) \\
55.3(0.71)\end{array}$ & $\begin{array}{r}26.3(0.80) \\
12.1(0.66) \\
8.2(0.68) \\
13.3(0.54) \\
44.8(0.66)\end{array}$ & $\begin{array}{l}17.7(0.78) \\
13.6(0.6 \overline{2}) \\
12.3(0.69) \\
15.8(0.51) \\
45.5(0.71)\end{array}$ \\
\hline $\begin{array}{r}42.3(0.83) \\
9.9(0.04)\end{array}$ & $\begin{array}{r}39.4(0.80) \\
6.7(0.04)\end{array}$ & $\begin{array}{l}41.7(0.81) \\
12.2(0.05)\end{array}$ & $\begin{array}{l}23.6(0.65) \\
18.3(0.10)\end{array}$ & $\begin{array}{l}20.9(0.67) \\
15.0(0.09)\end{array}$ & $\begin{array}{l}21.0(0.66) \\
13.9(0.10)\end{array}$ \\
\hline
\end{tabular}


into glycosaminoglycans of normal liver slices is not affected by serum from either normal rats or animals injured for various times with $D$-galactosamine. Both the fraction and the total amount of heparan sulfate synthesized are also unsusceptive to serum. The biphasic modulation of formation of total glycosaminoglycans in slices from livers injured for various times with $D$-galactosamine is not significantly influenced by serum from either normal or injured rats, which is also true for the synthesis of heparan sulfate, chondroitin sulfate, and dermatan sulfate (tab. 2). Thus, neither the inhibitory nor the stimulatory phase of liver glycosaminoglycan production seems to be mediated by factor(s) residing in the serum (see also fig. 2).

Action of p-nitrophenyl- $\beta$-D-xylopyranoside on galactosamine-induced inhibition of $\left[{ }^{35} \mathrm{~S}\right]$ sulfate incorporation into total liver glycosaminoglycans

From the results described in figure 2 and 4 it can be deduced that the inhibition of heparan sulfate synthesis might be due to a depression of the production of the core protein moiety of the proteoglycan. Consequently, the introduction of an artificial polysaccharide chain acceptor molecule into the cells, e.g. $p$-nitrophenyl- $\beta$-D-xyloside, should partially overcome galactosamine-induced inhibition of glycosaminoglycan synthesis. It was found (tab. 3) that in the presence of $1 \mathrm{mmol} / \mathrm{l} p$-nitrophenyl$\beta-D$-xyloside the formation of total glycosaminoglycans and of heparan sulfate is reduced to 0.70 of that measured in slices incubated in the absence of this compound. Under conditions of nearly complete inhibition of total glycosaminoglycan synthesis $(0.5 \mathrm{mmol} / 1$ puromycin) $p$-nitrophenyl- $\beta-D$-xyloside is able to increase $\left[{ }^{35} \mathrm{~S}\right]$ sulfate incorporation about 2.5 fold. However, the inhibition of heparan sulfate production induced by $1 \mathrm{mmol} / 1$ of $D$-galactosamine ( 0.24 of control) is not partially reversed by $p$-nitrophenyl- $\beta-D$-xyloside; instead, a further slight decline, similar to that measured in untreated liver slices, was found (tab. 3 ). Thus, the results do not support the view that diminished core protein synthesis is the only mechanism of action of $D$-galactosamine on hepatic glycosaminoglycan synthesis.

\section{Effects of diethyldithiocarbamate and of $(+)$ cianidanol-3 on the inhibition of glycosaminoglycan synthesis in galactosamine-injured liver}

Pretreatment of rats with a single dose of diethyldithiocarbamate ( $300 \mathrm{mg} / \mathrm{kg}$ body weight) results in a partial reversibility of the inhibition of $\left[{ }^{35} \mathrm{~S}\right]$ sulfate incorporation into total liver glycosaminoglycans produced by $D$-galactosamine (tab. 4). In addition, the "hepatoprotective" compound elevates the diminished fraction of heparan $\left[{ }^{35} \mathrm{~S}\right]$ sulfate in diseased liver from 0.52 to 0.69 . Thus, heparan sulfate synthesis in acutely, $D$. galactosamine-damaged livers is increased over 6-fold
Tab. 3. The effect of $p$-nitrophenyl- $\beta$ - $D$-xylopyranoside on the puromycin or $D$-galactosamine-induced inhibition of ${ }^{35}$ S I sulfate incorporation into liver glycosaminoglycans and heparan sulfate. Slices were prepared from untreated rat livers and incubated in medium supplemented with $0.93 \mathrm{MBq}$ of $\left[{ }^{35} \mathrm{~S}\right]$ sulfate either in the absence or presence of the additions given in the table. The final concentrations are listed in parenthescs. Since $p$-nitrophenyl$\beta$ - $D$-xyloside was dissolved in $0.5 \mathrm{~mol} / \mathrm{l}$ dimethylsulfoxide an appropriate volume of this solvent was added to the incubations without $p$-nitrophenyl- $\beta$ - $D$-xyloside. Under these conditions dimethylsulfoxide did not affect the incorporation. The data are from one representative experiment out of three.

\begin{tabular}{|c|c|c|c|}
\hline $\begin{array}{l}\text { Additions } \\
\text { to the incubation }\end{array}$ & $\begin{array}{l}\left.{ }^{35} \mathrm{~S}\right] \text { Sulfate } \\
\text { in total } \\
\text { glycos- } \\
\text { amino- } \\
\text { glycans } \\
\text { (kBq/g } \\
\text { protein) }\end{array}$ & $\begin{array}{l}\left.{ }^{35} \mathrm{~S}\right] \text { Sulfate } \\
\text { in heparan } \\
\text { sulfate } \\
(\mathrm{kBq} / \mathrm{g} \\
\text { protein) }\end{array}$ & $\begin{array}{l}\text { Heparan } \\
\left.\text { [ }^{35} \mathrm{~S}\right] \text { sulfate } \\
\text { (fraction of } \\
\text { total }\left.\right|^{35} \mathrm{~S} \text { - } \\
\text { glycosamino- } \\
\text { glycans) }\end{array}$ \\
\hline None & 29.8 & 24.7 & 0.83 \\
\hline $\begin{array}{l}\text { p-Nitrophenyl- } \\
\beta \text {-D-xyloside } \\
(1 \mathrm{mmol} / \mathrm{l})\end{array}$ & 21.0 & 17.4 & 0.83 \\
\hline $\begin{array}{l}\text { Puromycin } \\
\qquad(0.5 \mathrm{mmol} / 1)\end{array}$ & 2.2 & 1.7 & 0.78 \\
\hline $\begin{array}{l}\text { Puromycin } \\
+p \text {-nitrophenyl- } \\
\beta \text { - } D \text {-xyloside }\end{array}$ & 5.1 & 3.2 & 0.63 \\
\hline $\begin{array}{l}\text { Galactosamine } \\
\qquad(1 \mathrm{mmol} / 1)\end{array}$ & 9.4 & 5.9 & 0.63 \\
\hline $\begin{array}{l}\text { Galactosamine } \\
+p \text {-nitrophenyl- } \\
\beta \text { - } D \text {-xyloside }\end{array}$ & 6.2 & 3.7 & 0.59 \\
\hline
\end{tabular}

by application of diethyldithiocarbamate 45 min prior to injection of the toxic drug. It should be noted, that the protective compound reduced, in normal liver, the production of labeled glycosaminoglycans, without affecting significantly the relative proportion of heparan $\left[{ }^{35} \mathrm{~S}\right]$ sulfate (tab. 4). The flavonoid (+)cianidanol-3 partially rescues glycosaminoglycan synthesis from inhibition by $D$-galactosamine (tab. 4); its effect, however, is dependent on the action of $D$-galactosamine. If total glycosaminoglycan production is more severely inhibited the protective capacity of the flavonoid is more pronounced and equals that of diethyldithiocarbamate (not shown).

\section{Discussion}

The results presented in this study indicate clearly biphasic temporal changes in the incorporation of $\left[{ }^{35} \mathrm{~S}\right]$ sulfate into various types of liver glycosaminoglycans. The rate of isotope incorporation probably equals the rate of carbohydrate chain synthesis since there was no significant change in injured liver of the specific radioactivity of the immediate precursor of glycosaminoglycan sulfation, $3^{\prime}$-phosphoadenosine- 5 '-phosphosulfate, and it has not been shown so far, that sulfate groups of 
Tab. 4. The effect of diethyldithiocarbanate and of (+)cianidanol-3, respectively, on the galactosamine-induced inhibition of glycosaninoglycan synthesis in liver.

Rats were injected in vivo with $700 \mathrm{mg} / \mathrm{kg}$ body weight of $D$-galactosamine (diethyldithiocarbamate experiment) or $450 \mathrm{mg} / \mathrm{kg}$ body weight (cianidanol experiment), or a similar volume of saline instead of galactosamine (control rats). Diethyldithiocarbamate $(300 \mathrm{mg} / \mathrm{kg}$ body weight) was administered $45 \mathrm{~min}$ before the application of galactosamine. $2 \mathrm{~h}$ after injection of galactosamine the rats were sacrified. $(+$ ) Cianidanol-3 (a suspension of 250 $\mathrm{mg} / \mathrm{kg}$ body weight in saline) was applied intraperitoneally $48 \mathrm{~h}, 24 \mathrm{~h}$. and $3 \mathrm{~h}$ beforc injection of $D$-galactosamine into the rats. $3 \mathrm{~h}$ after administration of galactosamine the animals were decapitated. The liver slices were prepared and incubated with $1^{35} \mathrm{~S}$ ] sulfate as described. The values are the mean \pm S.D. of 3 experiments. The relative changes of total glycosaminoglycan synthesis are listed in parentheses.

\begin{tabular}{lll}
\hline $\begin{array}{l}\text { Source } \\
\text { of liver }\end{array}$ & $\begin{array}{l}\text { Total glycosamino- } \\
\text { glycan synthesis } \\
\text { (kBq/g protein) }\end{array}$ & $\begin{array}{l}\text { Heparan } \\
\text { sulfate } \\
\text { (fraction of } \\
\text { total glycos- } \\
\text { aminoglycans) }\end{array}$ \\
& & \\
\hline
\end{tabular}

\begin{tabular}{|c|c|c|c|}
\hline & $\begin{array}{l}\text { Diethyl- } \\
\text { dithio- } \\
\text { carbam- } \\
\text { atce }\end{array}$ & & \\
\hline Control rat & $\overline{+}$ & $\begin{array}{ll}40.7 \pm & 0.9(1.0) \\
24.8 \pm & 0.1(0.61)\end{array}$ & $\begin{array}{l}0.75 \pm 0.01 \\
0.81 \pm 0.03\end{array}$ \\
\hline Galactosamine rat & $\begin{array}{l}- \\
+ \\
(+) C i a n i d- \\
\text { anol-3 }\end{array}$ & $\begin{aligned} & 3.3 \pm 0.4(0.08) \\
& 15.4 \pm 0.6(0.38)\end{aligned}$ & $\begin{array}{l}0.52 \pm 0.02 \\
0.69 \pm 0.003\end{array}$ \\
\hline Control rat & $\overline{+}$ & $\begin{array}{l}37.6 \pm 7.4(1.0) \\
35.8 \pm 10.4(0.95)\end{array}$ & $\begin{array}{l}0.80 \pm 0.01 \\
0.82 \pm 0.05\end{array}$ \\
\hline Galactosamine rat & $\overline{+}$ & $\begin{array}{l}21.4 \pm 8.2(0.56) \\
28.8 \pm 10.2(0.77)\end{array}$ & $\begin{array}{l}0.73 \pm 0.04 \\
0.78 \pm 0.06\end{array}$ \\
\hline
\end{tabular}

liver glycosaminoglycans turn over independently from the carbohydrate chain backbone. The cyclic modulation of the synthesis of sulfated liver proteoglycans in response to acute injury obviously is qualitatively independent of the type and mechanism of action of the noxious agent, which is true at least for $D$-galactosamine and thioacetamide, but likely also for others (e.g. carbon tetrachloride, dimethylnitrosamine). Thus, the scheme presented in figure 5 can probably be generalized for a variety of acute, toxic liver injuries.

The inhibition of the synthesis of proteoheparan sulfate observed in the first phase (fig. 5) might play a pivotal role in the multistep process of liver cell damage (36) or, in the initiation of cell division following injury (37). Both assumptions arise from the previously discussed (28) and above briefly mentioned physiological functions of pericellular proteoheparan sulfate $(6,9-12)$. In addition to the key role of changes of the plasmalemma in the pathogenesis of toxic liver injury (38-41) structural alterations of the glycocalyx may have importance for

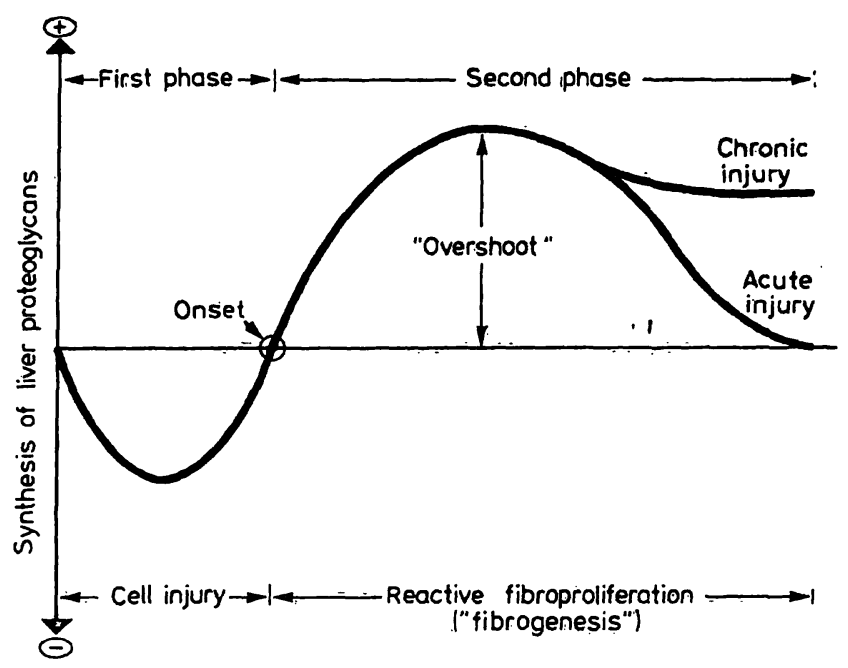

Fig. 5. Schematic presentation of the biphasic changes of proteoglycan synthesis in acutely injured liver. The underlying experimental results are given in this study.

the loss of the coordinate exchange of metabolites and ions across the cellular barrier which is an early sign of cellular damage.

Under the protective effects of diethyldithiocarbamate (42) and of the natural flavonoid (*)cianidanol-3 $(43-45)$ on the development of galactosamine-hèpatitis, a less pronounced inhibition of proteoglycan synthesis was observed. Clearly, the experiments do not decide whether this result is a consequence of less severe hepatic damage or vice versa.

As already mentioned depletion of cell surface proteoheparan sulfate might trigger the proliferation of liver cells probably by facilitating the influx of cell-surface: membrane associated $\mathrm{Ca}^{2+}$ into the cytosol (46). A transient increase in cytosolic free $\mathrm{Ca}^{2+t}$ appears to be required for enhanced proliferative tendency of normal and transformed cells (47). Thus, changes in the composition of sulfated glycosaminoglycans result in differences in the metal ion binding/release characteristics and by this might affect the intracellular availability of pericellular $\mathrm{Ca}^{2+}(48)$. In accordance with this assumption we found recently deminished synthesis of proteoheparan sulfate in regenerating rat liver (49). Undoubtedly, more detailed studies on the cell coat of isolated membranes from preinjured liver cells are required to solve these problems.

The biochemical mechanisms underlying the inhibition of synthesis of proteoheparan sulfate and to some degree of chondroitin sulfate and dermatan sulfate are not clear. From previous results (28) it was assumed that diminished core protein synthesis of proteoheparan sulfate might be crucial, a suggestion, which is indirectly supported here by showing the parallelism of inhibited proteoglycan and general protein synthesis in early stages of liver injury. However, we failed to counteract galactosamine-induced inhibition of heparan sulfate synthesis 
with $p$-nitrophenyl- $\beta-D$-xyloside, an artificial acceptor of the polysaccharide chains $(50,51)$, whereas in puromycin-treated slices a slight improvement was achieved. The latter finding confirms previous results which show partial restoration of hepatocellular heparan sulfate synthesis by $p$-nitrophenyl- $\beta$ - $D$-xyloside in the absence of protein synthesis (52). If technical reasons for this failure are excluded, one might assume that proteoglycan synthesis in galactosamine-damaged liver is impaired (also) at later biosynthetic steps, e.g. at the level of chain initiation and/or elongation.

The stimulated synthesis of proteoglycans in later stages of acute injury ("overshoot" phenomenon of the second phase in fig. 5) deserves special interest since it may represent initial biochemícal features of a process leading to active accumulation of glycosaminoglycans during long-term injury (27). It is of importance that the synthesis of chondroitin sulfate and dermatan sulfate, which are the preponderant types of sulfated glycosaminoglycans in fibrotic liver tissue (2.53), is mostly exaggerated. The cellular source of chondroitin sulfate and dermatan sulfate synthesis needs to be clarified before any conclusive studies on the molecular mechanisms of disease-associated stimulation can be made. Since the hepatocyte synthesizes nearly exclusively chondroitin ABC-lyase-resistant glycosaminoglycans $(6,9,54)$ the biosynthetic capacity of non-parenchymal liver cells (mainly sinusoidal lining cells) and of infiltrated in-

\section{References}

1. Delbrück, A. (1968) Z. Klin. Chem. Klin. Biochem. 6. $460-466$.

2. Kojima, J., Nakamura, N.. Kanatani, M. \& Ohmori, K. (1975) Cancer Res. 35, 542-547.

3. Dietrich, C. P., Sampaio, L. O. \& Toledo, O. M. S. (1976) Biochem. Biophys. Res. Commun. 71, 1-10.

4. Köster-Eiserfunke, W., Gressner, A. M. \& Greiling, H. (1980) Abstr. VII. Europ. Symp. Connect. Tissue Res. 145-146.

5. Gressner, A. M., Pazen, H. \& Greiling, H. (1977) HoppeSeyler's Z. Physiol. Chem. 358, 825-833.

6. Oldberg, A., Höök, M., Öbrink, B., Pertoft, H. \& Rubin, K. (1977) Biochem. J. 164, 75-81.

7. Koizumi, T., Nakamura, N. \& Abe, H. (1967) Biochim. Biophys. Acta 148, 749 - 75.6 .

8. Gregoire, P. E., Dictus-Vermeulen, C. \& Ameryckx, J. P. (1972) Biochim. Biophys. Acta 279, 102-117.

9. Yamamoto, K. \& Terayama, H. (1973) Canc. Res. 33, 2257-2264.

10. Akasaki, M., Kawasaki, T. \& Yamashina, I: (1975) FEBS Lett. 59, 100-104.

11. Oldberg, A., Kjellén, L. \& Höök, M. (1979) J. Biol. Chem. $254,8505-8510$.

12. Lis, D. \& Monis, B. (1979) J. Supramolec. Structure 12, 15-22.

13. Kraemer, P. M. (1971) Biochemistry 10, 1445-1451.

14. Ohnishi, T., Ohshima, E. \& Ohtsuka, M. (1975) Exp. Cell. Res. 93, 136-142.

15. Ohnishi, T., Yamamoto, K. \& Terayama, H. (1973) Histochemie 36, 15-20.

16. Rojkind, M. \& Kershenobich, D. (1976) in Progress in Liver Diseases (Popper,.H. \& Schaffner, F., eds.) Grune and Stratton, New York, 294-310.

17. Gressner, A. M. (1980) Med. Welt 31, 11-16. flammatory cells, e.g. or polymorphonuclear leucocytes and monocytes (55) has to be analysed.

A great variety of metabolic processes in the liver are controlled by humoral factors of hormonal and nonhormonal nature. The effect of serum factors on proteoglycan synthesis in other systems than liver, e.g. in embryonic cartilage, is well documented (56-59). Amazingly, neither inhibition and stimulation of total hepatic glycosaminoglycan synthesis nor the pattern of specific types was found to be affected by serum from normal or from injured rats. Thus glycosaminoglycan formation in liver explants in short-term culture seems to be refractory to the action of serum mediators. Possible reasons might be the relative short incubation period, saturating intracellular concentrations of the mediators during the time of incubation, a rapid inactivation of the serum factors in vitro or, less likely, an unresponsiveness of liver cells to the respective serum components. The former reasons might explain, why, in monolayer cultures of rat hepatocytes, heparan sulfate synthesis is strongly reduced in the presence of fetal calf serum (observation mentioned in l.c. (54)).

\section{Acknowledgement}

Wc are grateful to Mrs. Elke Stecklum for expert technical assistance.

18. Gressner, A. M. (1981) Krankenhausarzt 54, in press.

19. Reutter, W., Lesch, R., Keppler, D. \& Decker, K. (1968) Naturwissenschaften 55, 497.

20. Keppler, D., Lesch, R., Reutter, W. \& Decker, K. (1968) Exp. Mol. Pathol. 9, 279-290.

21. Decker, K. \& Keppler, D. (1974) Rev. Physiol. Biochem. Pharmacol. 71, 78-106.

22. Brodehl, J. (1961) Klin. Wochenschr. 39, 956-962.

23. Ashworth. C. T., Werner, J. D., Glass, M. D. \& Arnold. N. J. (1965) Amer. J. Pathol. 47, 917-932.

24. Lesch, R., Keppler, D., Reutter, W., Rudigier, J., Oehlert, W. \& Decker, K. (1970) Virchows Arch. Abt. B Zellpath. 6 . $57-71$.

25. Funatsu, K., Ishii, H., Shigeta, Y., Morita, A. \& Tsuchiya, M. (1978) Acta Hepato-Gastroenterol. 25, 97-104.

26. Fitzhugh, O. G. \& Nelson, A. A. (1948) Science 108. 626-628.

27. Gressner, A. M., Pazen, H. \& Greiling, H. (1977) Experientia 33, 1290-1292.

28. Gressner, A. M. \& Köster-Eiserfunke, W. (1981) J. Clin. Chem. Clin. Biochem. 19, 363-370.

29. Greiling, H. \& Stuhlsatz, H. W. (1969) Hoppe-Seyler's Z. Physiol. Chem. 350, 449-456.

30. Lowry, O. H., Rosebrough, N. J., Farr, A. L. \& Randall, R. J. (1951) J. Biol. Chem. 193, 265-275.

31. Ping Wong, K. \& Yco, T. (1979) Biochem. J. 181, 107-110.

32. Mans, R. J. \& Novelli, G. D. (1961) Arch. Biochem. Biophys. $94,48-53$.

33. Bergmeyer, H. U. \& Bcrnt, E. (1974) in Mcthoden der enzymatischen Analyse (Bergmeyer, H. U., ed.) Vol. I. Verlag Chemie, Weinheim, 785-791.

34. Demetriou, J. A., Drewes, P. A. \& Gin, J. B. (1974) in Clinical Chemistry (Henry. R. J., Cannon, D. C. \& Winkelman, J. W., eds.) Harper and Row. New York, 873-88t. 
35. Nagel, W., IVillig. F. \& Schmidt. F. H. (1964) Klin. Wochenschr. 42, 447-449.

36. Farber, J. L. \& El-Mofty'. S. K. (1975) Am. J. Pathol. 81, 237-250.

37. Lesch. R. \& Reutter. W. (cds.) (1975) Liver Regeneration After Experimental Injury Stratton Intercontinental Book Corp.. New York, USA.

38. El-Mlofty, S., Scrutton, M. C., Serroni, A., Nicolini, C. \& Farber. J. L. (1975) Am. J. Pathol. 79, 579-596.

39. Reutter, W. \& Bachmann, W. (1971) Verh. Dtsch. Ges. Innere Med. 77. 1177.

40. Bachmann. W.. Harms, E., Hassels. B., Henninger, $H$. \& Reutter, W. (1977) Biochem. J. 166, 455-462.

41. Bachmann. W. \& Reutter, W. (1979) Hoppe-Seyler's Z. Physiol. Chem. 360, 81-87.

42. Homann. J.. Gebhardt, H.\& Hopf, F. (1980) Drug. Res. $30.6+5-6+7$.

43. Reutter. W.. Hassels. B. \& Lesch, R. (1975) Induction and prevention of galactosamine hepatitis, in New Trends in the Therapy of Liver Diseases (Bertelli, A., ed.) pp. 121-127, S. Karger.

44. Perrissoud. D. \& Weibel, I. (1980 Naunyn-Schmiedeberg's Arch. Pharmacol. 312, 285-291.

45. Reutter. W. \&. Hassels, B. (1981) Biochem. Pharmacol. 29, $2258-2259$.

46. Berridge. M. J. (1975) Adv. Cyclic Nucleotide Res. 6, 1-98.
47. Vannucchi, S., Del Rosso, M., Cella, C., Urbano, P. \& Chiarugi, V. P. (1978) Biochem. J. 170; 185-187.

48. Edward, M., Long, W. F., Watson, H. H. K. \& Williamson, F. B. (1980) Biochem. J. 188, 769-773.

49. Gressner, A. M., Cadenbach, J. \& Greiling, H. (1981) J. Clin. Chem. Clin. Biochem. 19, 465-469.

50. Galligani, L., Hopwood, J., Schwartz, N. B. \& Dorfman, A. (1975) J. Biol. Chem. 250, 5400-5406.

51. Robinson, H. C., Brett, M. J., Tralaggan, P. J., Lowther, D. A. \& Okayama, M. (1975) Biochem. J. 148, 25 r 34.

52. Sudhakaran, P. R., Sinn, W. \& voǹ Figura, K. (1981) HoppeSeyler's Z. Physiol. Chem. 362, 39-46.

53. Vierhaus, S., Stuhlsatz, H.W. \& Greiling, H. (1980) Abstr. VII. Europ. Symp. Connect. Tissue Res. 128-129.

54. Prinż, R., Klein, U., Sudhakaran, P. R., Sinn, W., Ullirịch, K. \& von Figura, K. (1980) Biochim. Biophys. Acta 630 , $402-413$.

55. Hasumi, F. \& Mori, Y. (1980) Biochem. Med. 23, 6-16.

56. Nevo, Z̈., Silbergeld, A. K. \& Mamet, R. (1978) Biochim. Biophys. Acta $541,76-83$.

57. Eisenbarth, G. S. \& Lebovitz, H. E. (1974) Prostaglandins 7, $11-18$.

58. Rendall, J. L. (1972) Biochem. Biophys. Res. Commun. 45, $1425-1429$.

59. Drezner, M. K., Neelon, F. A. \& Lebovitz, H. E. (1976) Biochim. Biophys. Acta 425, 521-531.

Prof. Dr. A. Gressner

Abteilung Klinische Chemie und Pathochemie

der Medizinischen Fakultät der Technischen Hochschule (RWTH)

Goethestr. 27-29

D-5100 Aachen 